\title{
Proceeding
}

Supplementary Issue: Spring Conferences of Sports Science. 15th Convention and Workshop of the International Network of Sport and Health Science, 5-8 June 2019. University of Las Palmas de Gran Canaria, Las Palmas de Gran Canaria, Spain.

\section{Territorial survey on the interest in sport in the local territory of "Gian Camillo Glorioso" school}

\author{
PAOLO LONGO , REMO MAROTTA, ANTONIO ROCCO BUGLIONE, STEFANO BIFULCO, ILARIA \\ VISCIONE \\ University of Salerno, Italy
}

\begin{abstract}
The latest survey by the Central Statistical Institute (ISTAT) in 2015 reports in Italy an increase in the number of sports practitioners compared to 2011. They are greater in girls and more distributed on the 4 age groups chosen as a representative sample. The chosen disciplines vary according to age classes and the previous survey, indicating a significant increase in dance for females and fitness for males. This study doesn't focus on any reasons for the choices, on the related to the study or work activities and the data don't emerge locally. The aim of the study is to investigate a limited area, an homogeneous sample based on high school students and to investigate possible motivations including the relationship with the study. Data show that more females $(63 \%)$ than males $(37 \%)$ replied to the questionnaire and that a third of the students study 3 hours a day. $60 \%$ of students practices sport and the most practiced ones are fitness (38\%), dance $(19 \%)$ and football $(16 \%)$. The lack of time due to the study prevents physical activity for a third of the students, followed by a lack of motivation (30\%) and facilities in the area (13\%). In conclusion, results suggest that the study circumscribed locally, with a representative sample of the reference population is more reliable and can be used as a basis for any actions to be taken. Keywords: Physical activity; Study; High school sport; Limited area.

\section{Cite this article as:}

Longo, P., Marotta, R., Buglione, A.R., Bifulco, S., \& Viscione, I. (2019). Territorial survey on the interest in sport in the local territory of "Gian Camillo Glorioso" school. Journal of Human Sport and Exercise, 14(4proc), S753-S760. doi:https://doi.org/10.14198/jhse.2019.14.Proc4.37
\end{abstract}

Corresponding author. University of Salerno, Italy.

E-mail: paololongo456@gmail.com

Supplementary Issue: Spring Conferences of Sports Science. 15th Convention and Workshop of the International Network of Sport and Health Science, 5-8 June 2019. University of Las Palmas de Gran Canaria, Las Palmas de Gran Canaria, Spain. JOURNAL OF HUMAN SPORT \& EXERCISE ISSN 1988-5202

(c) Faculty of Education. University of Alicante doi:10.14198/jhse.2019.14.Proc4.37 


\section{INTRODUCTION}

The sport and physical practice is one of the most important datum (Raiola, Di Tore, 2012) because it is very important to know if the people know the knowledge about physical activity (D'Isanto et al, 2019, Mazzeo et al, 2018, Raiola et al, 2018, Valentini et al, 2018, Sanseviero et al, 2018). To know the aspects about sport disability (Cassese, Raiola, 2018, Raiola, 2015ab), sport performance (Altavilla, Raiola, 2019, Rago, et al, 2016, Gaetano, Rago, 2014), sport assessment (Alminni et al, 2019, D'elia et a, 2019, Forte et al, 2019) sport leisure, sport pedagogy (Ceciliani, 2019, Ceciliani et al, 2005, D'Isanto 291, 2016), sport education (D'Elia, 2019), sport wellness (Severino et al, 2019) and health. The ISTAT survey of 2015 highlighted that there are about 20.2 million people of 3 years and more who practise in their spare time one or more sports, equal to $34.3 \%$ of the population. It remains in very high time the quota of sedentary, those who have declared not to practice sports or physical activity in the free time: after a strong decrease recorded between 2006 and 2010, (from $42.0 \%$ to $38.8 \%$ ), since 2010 , the quota of sedentary is stable to $39 \%$. Sport is a highly age-related leisure activity: from the age of 15, the interest in sports practice begins to decline even if the quota of practitioners is still elevated to 24 years (respectively $63.4 \%$ between 15 and 17 years and almost $54 \%$ between 18 and 24 years). The table no. 1 carry out the percentage.

Table 1. Answers A

\begin{tabular}{|l|l|l|l|l|l|l|l|l|l|}
\hline \multirow{2}{*}{$\begin{array}{l}\text { AGE } \\
\text { CLASS }\end{array}$} & \multicolumn{2}{|l|}{ THEY PRACTICE } & \multicolumn{5}{|c|}{ OF WHICH: } \\
\cline { 5 - 9 } & \multicolumn{2}{|l|}{ SPORTS } & & \multicolumn{5}{|c|}{ CONTINUOUSLY } & IN A SALTUARY WAY \\
\hline & MALES & FEMALES & $\begin{array}{l}\text { MALES \& } \\
\text { FEMALES }\end{array}$ & MALES & FEMALES & $\begin{array}{l}\text { MALES \& } \\
\text { FEMALES }\end{array}$ & MALES & FEMALES & $\begin{array}{l}\text { MALES \& } \\
\text { FEMALES }\end{array}$ \\
\hline $15-17$ & $69,60 \%$ & $56,40 \%$ & $63,40 \%$ & $58,10 \%$ & $41,40 \%$ & $50,00 \%$ & $11,50 \%$ & $15,00 \%$ & $13,20 \%$ \\
\hline $18-19$ & $71,10 \%$ & $47,70 \%$ & $59,60 \%$ & $54,00 \%$ & $33,20 \%$ & $43,80 \%$ & $17,10 \%$ & $14,50 \%$ & $15,80 \%$ \\
\hline
\end{tabular}

This ISTAT study was carried out on a national scale; therefore, the data obtained represents a generalized situation that doesn't enter into the specific case. The latest survey by the Central Statistical Institute (ISTAT) in 2015 reports an increase in the number of sports practitioners compared to 2011. They are greater in girls and more distributed on the 4 age groups chosen as a representative sample. The chosen disciplines vary according to age classes and the previous survey, indicating a significant increase in dance for females and fitness for males. This study doesn't focus on any reasons for the choices, on the related to the study or work activities and the data don't emerge locally. The problem that we want to observe is the absence of physical activity (Gaetano, 2016, Tiziana et al, 2017) in adolescence, related to high school study activity because it wants itself to establish hypokinetic aspects (Raiola, 2017, Raiola, Di Tore, 2017) and furthermore correlated aspect (Altavilla et al, 2015ab, Gaetano et al, 2015ab). The aim of the study is to investigate a limited area, an homogeneous sample based on high school students and to investigate possible motivations including the relationship with the study. In fact, the ISTAT survey shows that there is already a noticeable difference regarding the practice of physical activity between northern and southern Italy: these data show that a survey carried out at national level doesn't take into consideration territorial differences and therefore it is not possible to make personalized interventions as it is carried out at the table no.1. 
Table 2. Answers B

\begin{tabular}{cc}
\hline GEOGRAPHIC DISTRIBUTION & THEY PRACTICE SPORT \\
\hline Northern Italy & $39.95 \%$ \\
Central Italy & $35.3 \%$ \\
Southern Italy & $26.35 \%$ \\
\hline
\end{tabular}

\section{METHODS}

Based statistical survey through the use of an anonymous questionnaire to collect statistical data. The questionnaire was processed through Google moduli, which provided a link to complete it. The three representatives of the institute of the scientific and human sciences high school "IIS Gian Camillo Glorioso" of Montecorvino Rovella Avellino have created a WhatsApp group, which contained a student representative of each class. In the group, a link to complete the questionnaire was sent and each representative reported that same link on the WhatsApp group of their class, and so it arrived to all the students of the institute. In the following two days the students answered the questionnaire, at the end of which the data were recorded and the graphs with the results were created.

\section{Tools}

The questions in the questionnaire are:

- Gender

- Age

- What is the average of your grades at school?

- Have you ever repeated a school year?

- How many hours a day do you spend studying?

- Do you practice any sport activities?

- If yes, what activity do you do?

- If not, what's stopping you from doing it?

\section{Sample}

The sample is made by the students of the Montecorvino Rovella High School "IIS Gian Camillo Glorioso" scientific and human sciences for a total of 23 classes and 530 students.

\section{RESULT}

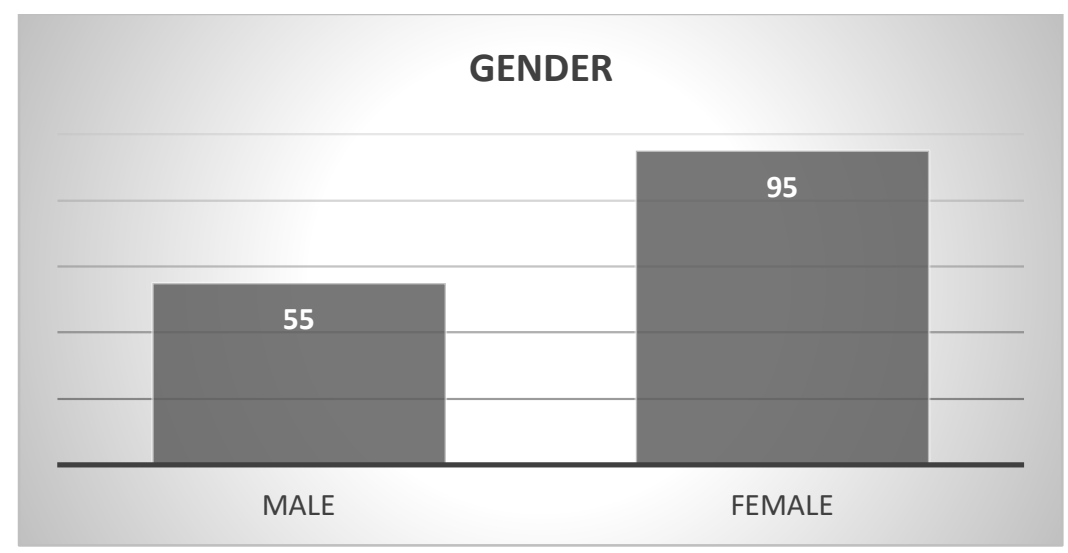

Figure 1. Answers C. 


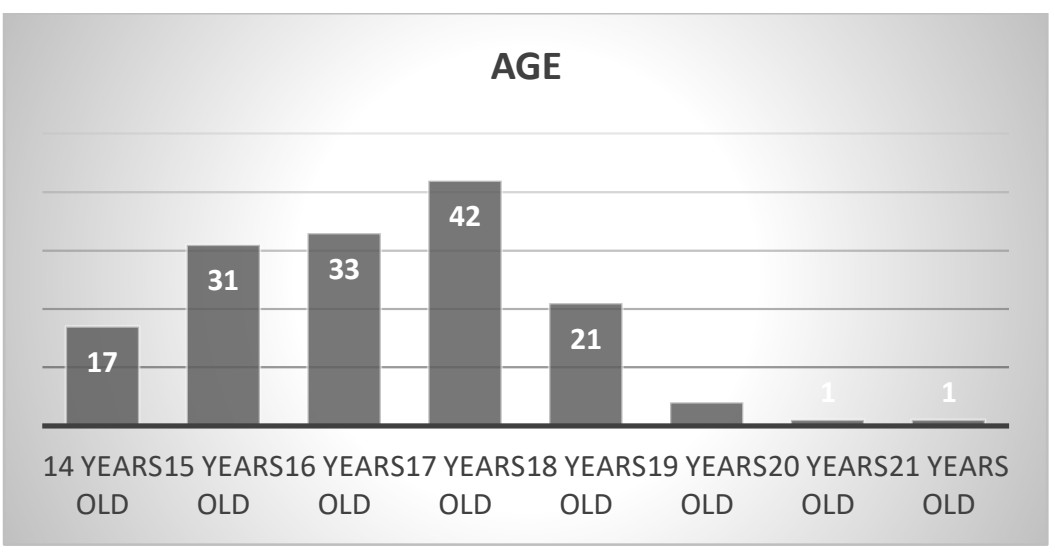

Figure 2. Answers D.

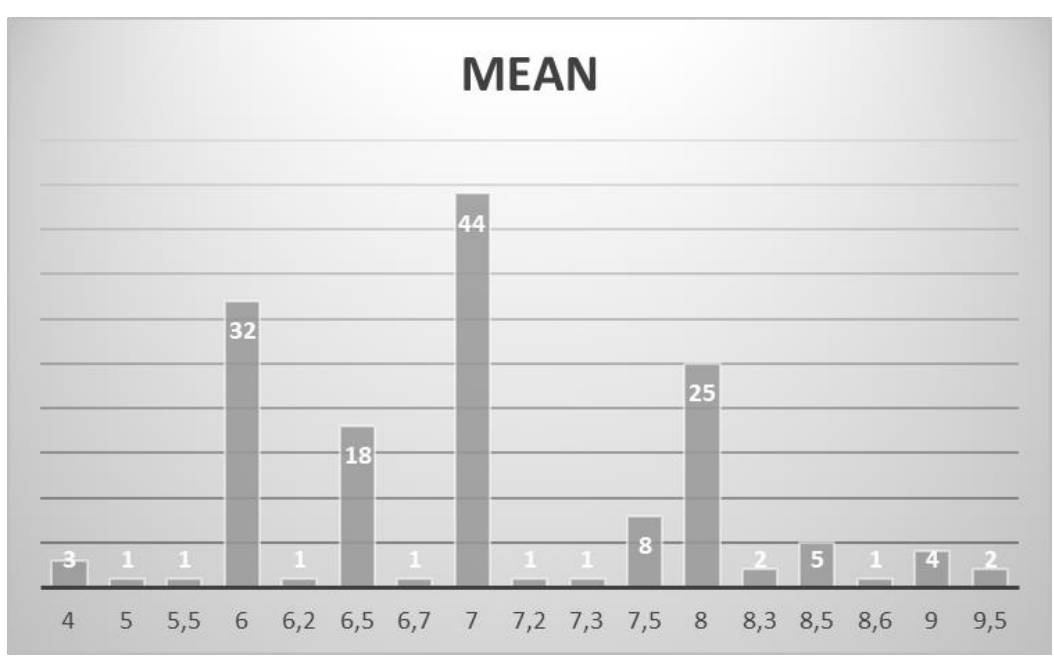

Figure 3. Answers E.

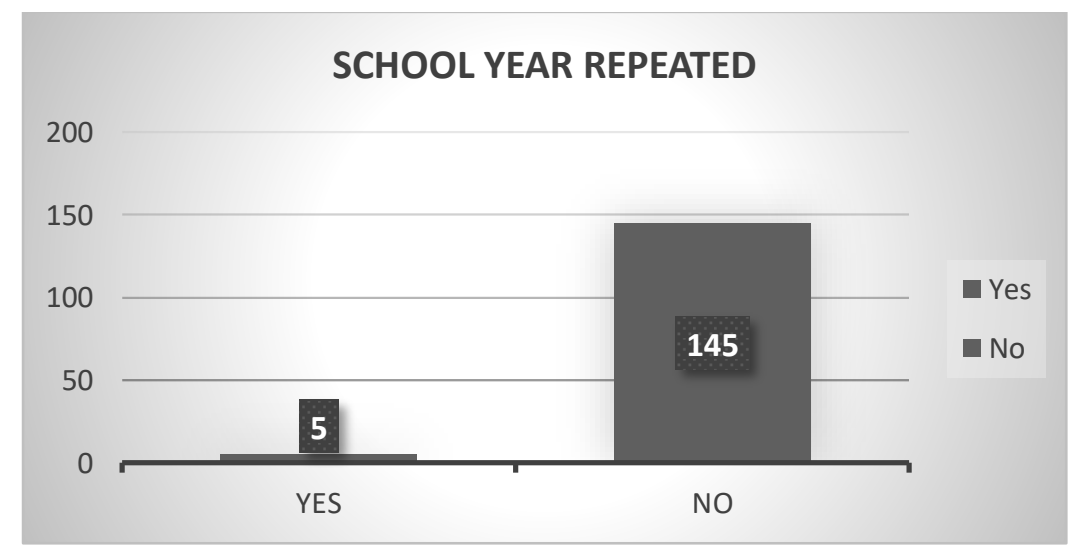

Figure 4. Answers F. 


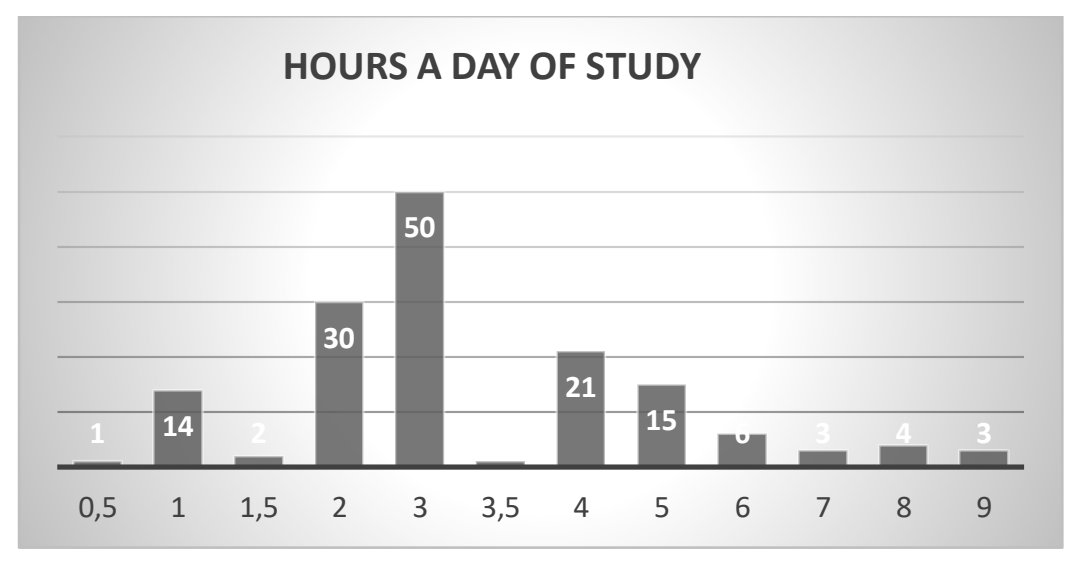

Figure 5. Answers E.

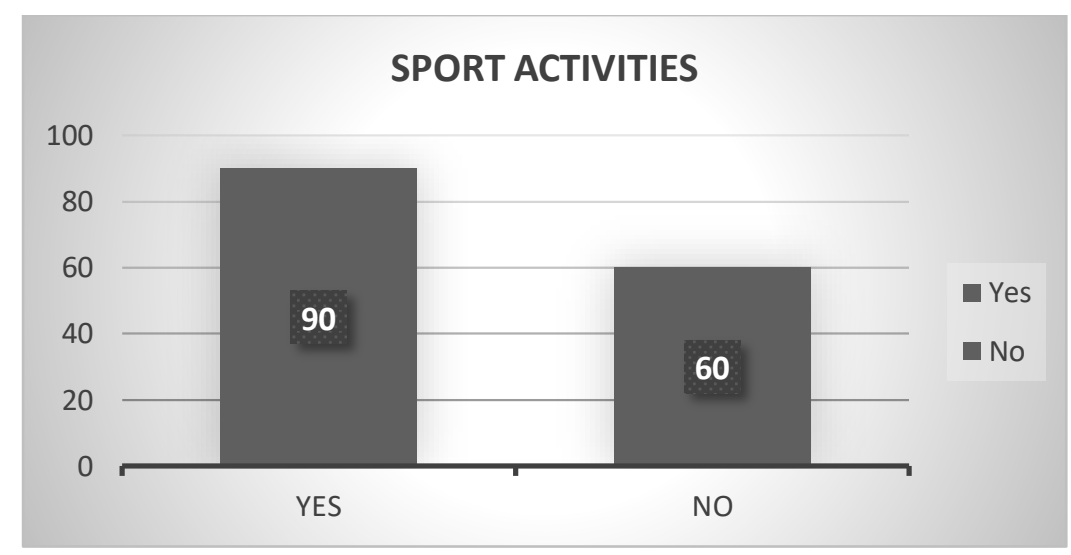

Figure 6. Answers F.

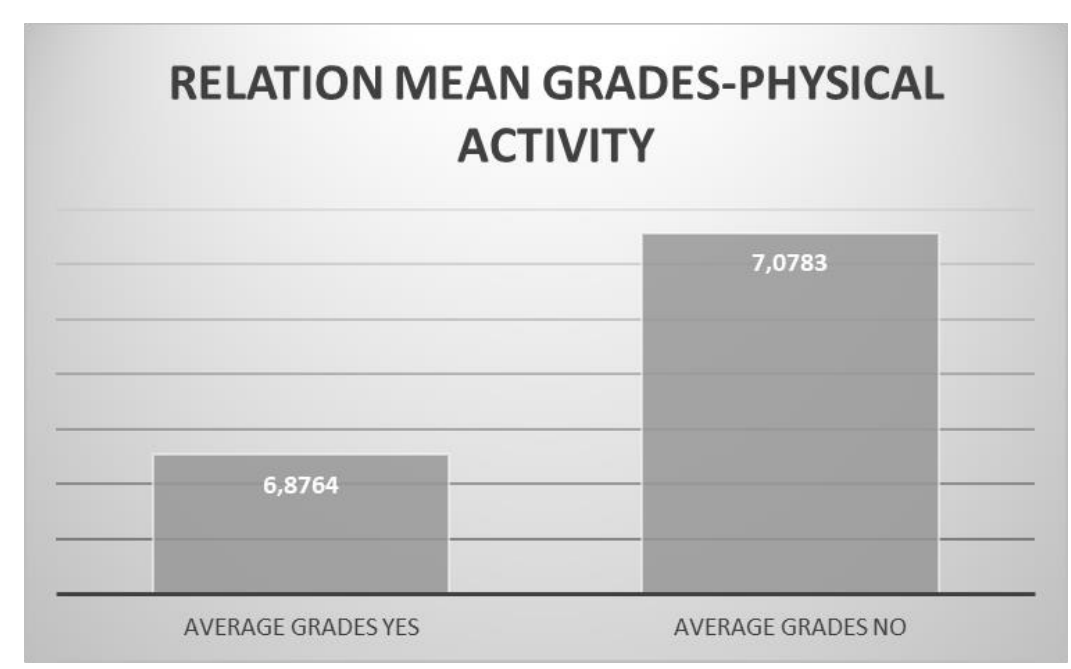

Figure 7. Answers G. 


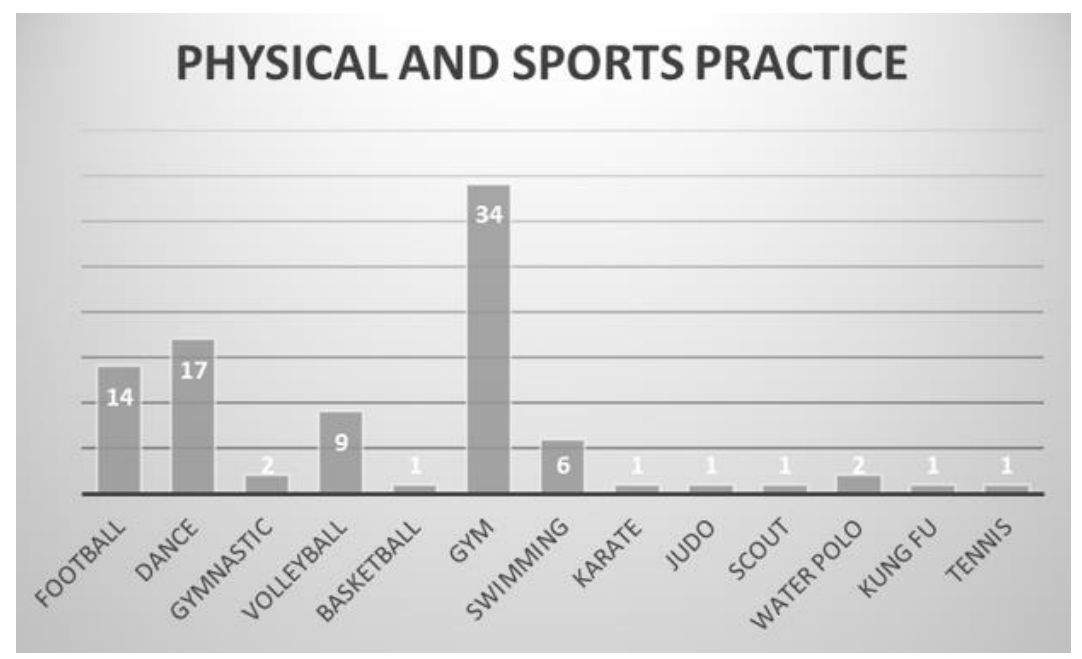

Figure 8. Answers H.

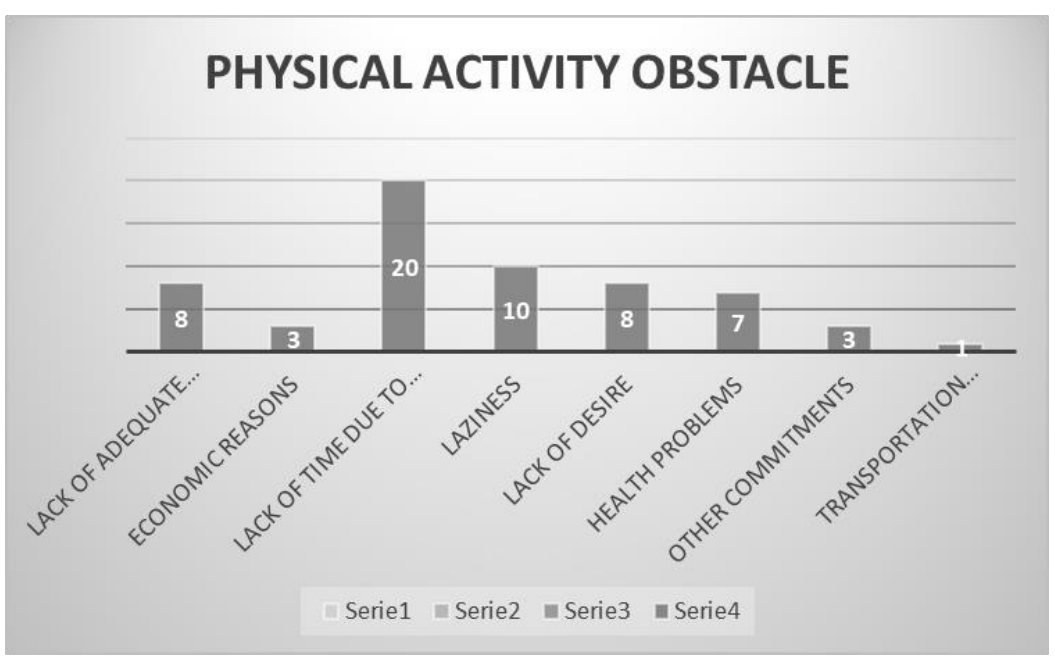

Figure 9. Answers I.

\section{DISCUSSION}

Data show that more females $(63 \%)$ than males $(37 \%)$ replied to the questionnaire and that a third of the students study 3 hours a day. $60 \%$ of students practices sport and the most practiced ones are fitness (38\%), dance $(19 \%)$ and football $(16 \%)$. The average school grades of those who practice sports $(60 \%)$ is 6.8764 , while that one of those who don't practice any sport (40\%) is 7.0783 . These data show that the average of the scholastic grades between those who practice physical activity and those who do not practice it is almost the same, even if the physical activity takes time away from the study. The lack of time due to the study prevents physical activity for a third of the students, followed by a lack of motivation (30\%) and facilities in the area $(13 \%)$. 


\section{CONCLUSION}

Results suggest that the study circumscribed locally, with a representative sample of the reference population is more reliable and can be used as a basis for any actions to be taken. Thus, it could be applied by the local Minister of education uses the institutional net of public school.

\section{REFERENCES}

Alminni, C., Altavilla, G., Cassese, F.P., Ceciliani, A., D'isanto, T. (2019) Physical and motor tests to estimate the improvement of the float serve, Journal of Human Sport and Exercise, 14 (Proc2), pp. S245-S250. https://doi.org/10.14198/hse.2019.14.proc2.13

Altavilla, G., Raiola, G. (2019)A brief review on physiological commitment in basketball: An interpretative key, Journal of Human Sport and Exercise, 14, pp. S59-S65. https://doi.org/10.14198/ihse.2019.14.proc1.07

Altavilla, G., Furino, F., Di Palmo, M., Raiola, G. (2015a) The child hypokinetic and the overtrained, Sport Science, 8, pp. 72-74.

Altavilla, G., Furino, F., Marika, D.P., Raiola, G. (2015b) Physical skills, sport learning and socio-affective education, Sport Science, 8, pp. 44-46.

Cassese, F.P., Raiola, G. (2017) The importance of sport in disability management, Sport Science, 10, pp. 7-11.

Ceciliani, A. (2018)From the embodied cognition to the embodied education in the physical and sports sciences, Encyclopaideia, 22 (51), pp. 11-24.

Ceciliani, A., Di Carlo, M., Tentoni, C. (2005)Mental process learning Medicina dello Sport, 58 (1), pp. 43-52.

D'Elia, F. (2019). The training of physical education teacher in primary school. Journal of Human Sport and Exercise, 14(1proc), S100-S104. https://doi.org/10.14198/hhse.2019.14.Proc1.12

D'Elia, F., D'Isanto, T., \& Altavilla, G. (2019). Training and performance in the transition period. Journal of Human Sport and Exercise, 14(2proc), S258-S262. https://doi.org/10.14198/ihse.2019.14.Proc2.15

D'isanto, T. (2019) Physical and sport education between Italian academic system and European Research Council structure panel, Journal of Human Sport and Exercise, 14, pp. S66-S76. https://doi.org/10.14198/ihse.2019.14.proc1.08

D'Isanto, T., D'Elia, F., Raiola, G., Altavilla, G. (2019)Assessment of sport performance: Theoretical aspects and practical indications, Sport Mont, 17 (1), pp. 79-82.

D'Isanto, T. (2016) Pedagogical value of the body and physical activity in childhood, Sport Science, 9, pp. 13-18.

Di Tore, P.A., Raiola, G. (2012) Case study on physical education and sport in Naples, Italy, Mediterranean Journal of Social Sciences, 3 (11), pp. 471-476.

Forte, D., Ceciliani, A., Izzo, R., Altavilla, G. (2019) Transition period: Pilot study on performance reduction of ability to jump in volleyball, Journal of Human Sport and Exercise, 14 (Proc2), pp. S221S227. https://doi.org/10.14198//hse.2019.14.proc2.09

Gaetano, R., Domenico, T., Gaetano, A. (2015a) Physical activity and its relation to body and ludic expression in childhood, Mediterranean Journal of Social Sciences, 6 (3), pp. 293-296. https://doi.org/10.5901/mjss.2015.v6n3s2p293

Gaetano, R., Paloma, F.G., Gaetano, A. (2015b) Anxiety in the youth physical and sport activity, Mediterranean Journal of Social Sciences, 6 (3), pp. 227-230. https://doi.org/10.5901/miss.2015.v6n3s2p227 
Gaetano, A. (2016) Relationship between physical inactivity and effects on individual health status, Journal of Physical Education and Sport, 16, pp. 1069-1074.

Gaetano, R., Rago, V. (2014) Preliminary study on effects of hiit-high intensity intermittent training in youth soccer players, Journal of Physical Education and Sport, 14 (2), pp. 148-150.

Mazzeo, F., Altavilla, G., D'elia, F., Raiola, G. (2018a) Development of doping in sports: Overview and analysis, Journal of Physical Education and Sport, 18 (3), pp. 1669-1677.

Mazzeo, F., D'elia, F., Raiola, G. (2018b) Drugs in sport: Doping development and ethical analysis, Sport Science, 11 (1), pp. 106-112.

Rago, V., Pizzuto, F., Raiola, G. (2017) Relationship between intermittent endurance capacity and match performance according to the playing position in sub-19 professional male football players: Preliminary results, Journal of Physical Education and Sport, 17 (2), pp. 688-691.

Raiola, G. (2015a) Inclusion in sport dance and self perception Sport Science, 8, pp. 99-102.

Raiola, G. (2017) Motor learning and teaching method, Journal of Physical Education and Sport, 17, pp. 2239-2243.

Raiola, G., Di Tore, P.A. (2017) Motor learning in sports science: Different theoretical frameworks for different teaching methods, Sport Science, 10, pp. 50-56.

Raiola, G., D'elia, F., Altavilla, G. (2018) Physical activity and sports sciences between European Research Council and academic disciplines in Italy, Journal of Human Sport and Exercise, 13, pp. S283-S295. https://doi.org/10.14198/jhse.2018.13.proc2.13

Raiola, G. (2015). Sport skills and mental health. Journal of Human Sport and Exercise, 10 (1proc), pp. S369-S376. https://doi.org/10.14198//hse.2015.10.Proc1.27

Statistics ISTAT (2015), Statistic document .pdf, Rome, Italy.

Sanseviero, I., Cassese, F.P., Fonzo, E., Altavilla, G., D'elia, F. (2019) Study on the master's degree in sciences of sports evaluation and sport for disabled at the University of Salerno, Italy. Journal of

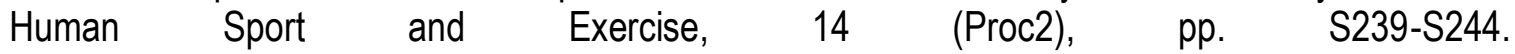
https://doi.org/10.14198/ihse.2019.14.proc2.12

Severino, N.C., Cassese, F.P., Ceciliani, A., D'elia, F., Di Tore, A.P. (2019) Psychophysical benefits of recreational five-a-side football, Journal of Human Sport and Exercise, 14 (Proc2), pp. S206-S214. https://doi.org/10.14198/ihse.2019.14.proc2.07

Tiziana, D., Antonetta, M., Gaetano, A. (2017) Health and physical activity, Sport Science, 10 (1), pp. 100-105.

Valentini, M., Riccardi, F., Raiola, G., Federici, A. (2018) Educational research: Motor area and relational area during children's personality development, Journal of Physical Education and Sport, 18, art. no. 327, pp. 2157-2174.

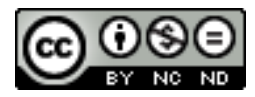

This work is licensed under a Attribution-NonCommercial-NoDerivatives 4.0 International (CC BY-NC-ND 4.0). 